\title{
Associations between apparent diffusion coefficient (ADC) and KI 67 in different tumors: a meta-analysis. Part 1: ADC $_{\text {mean }}$
}

\author{
Alexey Surov ${ }^{1, *}$, Hans Jonas Meyer ${ }^{1, *}$ and Andreas Wienke ${ }^{2, *}$ \\ ${ }^{1}$ Department of Diagnostic and Interventional Radiology, University of Leipzig, Leipzig, Germany \\ ${ }^{2}$ Institute of Medical Epidemiology, Biostatistics, and Informatics, Martin Luther University of Halle-Wittenberg, Halle, \\ Germany \\ *These authors contributed equally to this work
}

Correspondence to: Alexey Surov, email: Alexey.Surov@medizin.uni-leipzig.de

Keywords: diffusion weighted imaging, $A D C$, ki 67

Received: June 23, 2017 Accepted: August 15, 2017

Published: August 24, 2017

Copyright: Surov et al. This is an open-access article distributed under the terms of the Creative Commons Attribution License 3.0 (CC BY 3.0), which permits unrestricted use, distribution, and reproduction in any medium, provided the original author and source are credited.

\section{ABSTRACT}

Diffusion weighted imaging (DWI) is a magnetic resonance imaging (MRI) technique based on measure of water diffusion in tissues. This diffusion can be quantified by apparent diffusion coefficient (ADC). Some reports indicated that ADC can reflect tumor proliferation potential. The purpose of this meta-analysis was to provide evident data regarding associations between ADC and KI 67 in different tumors. Studies investigating the relationship between ADC and KI 67 in different tumors were identified.

MEDLINE library was screened for associations between ADC and KI 67 in different tumors up to April 2017. Overall, 42 studies with 2026 patients were identified. The following data were extracted from the literature: authors, year of publication, number of patients, tumor type, and correlation coefficients.

Associations between ADC and KI 67 were analyzed by Spearman's correlation coefficient. The reported Pearson correlation coefficients in some studies were converted into Spearman correlation coefficients.

The pooled correlation coefficient between ADC $_{\text {mean }}$ and $\mathrm{KI} 67$ for all included tumors was $\rho=\mathbf{0 . 4 4}$. Furthermore, correlation coefficient for every tumor entity was calculated. The calculated correlation coefficients were as follows: ovarian cancer: $\rho=-0.62$, urothelial carcinomas: $\rho=-0.56$, cerebral lymphoma: $\rho=-0.55$, neuroendocrine tumors: $\rho=-0.52$, glioma: $\rho=-0.51$, lung cancer: $\rho=-0.50$, prostatic cancer: $\rho=-0.43$, rectal cancer: $\rho=-0.42$, pituitary adenoma: $\rho=-0.44$, meningioma, $\rho=-0.43$, hepatocellular carcinoma: $\rho=-0.37$, breast cancer: $\rho=-0.22$.

\section{INTRODUCTION}

Diffusion weighted imaging (DWI) is a magnetic resonance imaging (MRI) technique based on measure of water diffusion in tissues [1]. This diffusion can be quantified by apparent diffusion coefficient (ADC) $[1,2]$. Furthermore, ADC can be divided into three sub-parameters: $\mathrm{ADC}$ minimum or $\mathrm{ADC}_{\text {min }}$, mean $\mathrm{ADC}$ or $\mathrm{ADC}_{\text {mean }}$ and $\mathrm{ADC}$ maximum or $\mathrm{ADC}_{\text {max }}$ [2]. Most frequently, $\mathrm{ADC}_{\text {mean }}$ is used in clinical and experimental investigations. Previously, numerous reports showed usefulness of DWI/ADC in oncology [3-8]. According to the literature, $\mathrm{ADC}$ values can discriminate malignant and benign lesions $[7,9]$. Typically, malignant tumors have lower values in comparison to benign lesions [7, 9]. For example, in head and neck region, malignant lymphomas had a mean ADC value of $0.66 \times 10^{-3} \mathrm{~mm}^{2} \mathrm{~s}^{-1}$, squamous and adenoid carcinomas $1.13 \times 10^{-3} \mathrm{~mm}^{2} \mathrm{~s}^{-1}$, while benign solid lesions presented with a mean ADC value of $1.56 \times 10^{-3} \mathrm{~mm}^{2} \mathrm{~s}^{-1}[9]$.

Furthermore, previous studies also mentioned that ADC can predict early response to treatment and clinical outcome in different malignancies $[3-7,10,11]$. So Papaevangelou et al. demonstrated an early increase of ADC values under cytostatic therapy in experimental colonic cancer [13]. Histopathological examination 
identified thereby a decrease of vital cells [12]. Moreover, numerous clinical investigations of different tumors, for example, ovarian carcinomas [10], lung, esophageal, gastric, rectal cancer or liver metastases showed similar results $[11,13]$.

These effects of ADC are based on its associations with several histopathological features. It has been shown that ADC correlated inversely with cell count of investigated lesions $[1,2,14]$. However, as suggested in a recent meta-analysis, this correlation is different in several tumors [14]. Thereby, correlation coefficients ranged from $\rho=-0.25$ in lymphoma to $\rho=-0.66$ in glioma [14].

As mentioned by some authors, ADC can also reflect other histopathological features, such as expression of different receptors, nucleic polymorphism, and proliferation potential [2]. Especially associations with proliferation, for example, with expression of MIB 1 or KI 67 receptor are very important because the fact that it predicts behavior of several tumors $[2,15]$. According to the literature, breast carcinomas with high expression of KI 67 had lower ADC values in comparison to tumors with low KI 67 expression [15]. Also in meningioma and cerebral lymphoma, ADC can distinguish between tumors with low and high expression of KI $67[16,17]$.

However, use of ADC as a biomarker of tumor proliferation is difficult because of several problems. Firstly, a wide spectrum of correlation coefficients between ADC and KI 67 was reported [17-59]. Secondly, most reports about associations between $\mathrm{ADC}$ and $\mathrm{KI}$ 67 investigated small samples ranging from 11 to 50 patients/tumors [17, 22-27]. There were only few studies investigated collectives over 100 patients [28-30].

The purpose of this meta-analysis was to provide evident data regarding associations between DWI, in particular $\mathrm{ADC}_{\text {mean }}$, and $\mathrm{KI} 67$ in different tumors.

\section{RESULTS}

The enrolled studies comprised 2026 patients with several tumors. Most frequently, different breast tumors $(28.28 \%)$, followed by glioma (10.81\%), urothelial carcinomas $(10.41 \%)$, neuroendocrine tumors $(9.53 \%)$, rectal cancer $(7.75 \%)$, menigioma $(5.43 \%)$, and hepatocellular carcinoma $(5.13 \%)$ were reported (Table 1$)$. Other tumors were rarer.

The pooled correlation coefficient between $\mathrm{ADC}_{\text {mean }}$ and $\mathrm{KI} 67$ for all included tumors (Figure 1) was $\rho=-0.44,(95 \% \mathrm{CI}=[-0.51 ;-0.37])$, heterogeneity $\tau^{2}=$ $0.03,(p<0.00001), \mathrm{I}^{2}=74 \%$, test for overall effect $\mathrm{Z}=$ $12.43(p<0.00001)$.

Furthermore, correlation coefficient for every tumor entity was calculated. For this sub-analysis, only data for primary tumors were acquired and tumor entities with less than three reports were excluded. Overall, 12 tumor entities with 1778 patients were included into the subanalysis (Table 2). The calculated correlation coefficients were as follows: ovarian cancer: $\rho=-0.62(95 \% \mathrm{CI}=$ $[-0.75 ;-0.49])$; urothelial carcinomas: $\rho=-0.56(95 \%$ $\mathrm{CI}=[-0.65 ;-0.47])$; cerebral lymphoma: $\rho=-0.55$ (95\% CI $=[-0.88 ;-0.23])$; neuroendocrine tumors: $\rho$ $=-0.52(95 \% \mathrm{CI}=[-0.64 ;-0.39])$; glioma: $\rho=-0.51$ (95\% CI $=[-0.69 ;-0.32])$; lung cancer: $\rho=-0.50(95 \%$ $\mathrm{CI}=[-0.92 ;-0.07])$; prostatic cancer: $\rho=-0.43(95 \%$ $\mathrm{CI}=[-0.61 ;-0.25])$; rectal cancer: $\rho=-0.42(95 \% \mathrm{CI}=$ $[-0.55 ;-0.29])$; pituitary adenoma: $\rho=-0.44(95 \% \mathrm{CI}=$ $[-1.00 ; 0.13])$; meningioma, $\rho=-0.43(95 \% \mathrm{CI}=[-0.65$; $-0.20])$; hepatocellular carcinoma: $\rho=-0.37$ (95\% CI $=[-0.54 ;-0.20])$; breast cancer: $\rho=-0.22(95 \% \mathrm{CI}=$ $[-0.50 ; 0.06])$ (Figure 2).

\section{DISCUSSION}

To the best of our knowledge, this is the first metaanalysis regarding associations between ADC and KI 67 in different tumors based on a large sample. As seen, in the general collective, ADC correlates moderately with KI 67.

Some previous investigations identified the phenomenon that ADC can be associated with KI 67 $[2,17,22,24,29,56]$. The exact cause of this association is unclear. KI 67 is a nonhistone, nuclear protein synthesized throughout the whole cell cycle except the G0 phase, and has been shown to be responsible for cell proliferation $[60,61]$. It is well known that the nucleic size increases during mitosis [62]. Previous investigations identified statistically significant correlations between nucleic size/volume and ADC [2, 22, 51, 63]. Furthermore, intracellular water diffusion may be affected by numerous mitotic membranes and tubular structures [64]. It is also possible that mitotic phases may induce an increase of cytoplasmic proteins and, therefore, increase of cytoplasmic viscosity [65]. This may also decrease ADC.

Independent of possible pathomechanisms of interaction between ADC and KI 67, a key question is how ADC is helpful to predict proliferation potential of investigated tumors or not. Our analysis showed that the reported data about associations between ADC and KI 67 are very inconsistent. While some authors identified significant correlations between the parameters, other did not. Presumably, several tumors may show also different relationships between ADC and KI 67. In fact, our metaanalysis confirmed this hypothesis. In ovarian cancer, ADC correlated well with KI 67. This finding suggests the possibility to use ADC as a biomarker for proliferation in this tumor. In most investigated tumors, such as in urothelial carcinoma, lung cancer, cerebral lymphoma, and neuroendocrine tumors ADC correlated moderately with KI 67 and the correlation coefficients ranged from -0.50 to -0.56 . Hence, we postulate that ADC may be used as an additional surrogate marker for proliferation potential for these tumors, however, his validity is restricted.

Furthermore, weak-to-moderate correlations between $\mathrm{ADC}$ and $\mathrm{KI} 67$ were identified in meningiomas, 
Table 1: Overview about all involved tumor types

\begin{tabular}{lcc}
\hline Diagnosis & $\boldsymbol{n}$ & $\mathbf{\%}$ \\
\hline Different breast tumors and tumor like lesions & 573 & 28.28 \\
Glioma & 219 & 10.81 \\
Urothelial carcinoma & 211 & 10.41 \\
Neuroendocrine tumor & 193 & 9.53 \\
Rectal cancer & 157 & 7.75 \\
Meningioma & 110 & 5.43 \\
Hepatocellular carcinoma & 104 & 5.13 \\
Ovarian tumor & 86 & 4.25 \\
Prostatic cancer & 81 & 4.00 \\
Lung cancer & 51 & 2.52 \\
Cerebral lymphoma & 49 & 2.42 \\
Pituary adenoma & 41 & 2.02 \\
Brain metastases & 32 & 1.58 \\
Pancreatic cancer & 28 & 1.38 \\
Different brain tumors & 26 & 1.28 \\
Uterine cervical cancer & 21 & 1.04 \\
Liver metastases & 19 & 0.94 \\
Thyroid cancer & 14 & 0.69 \\
Head and neck cancer & 11 & 0.54 \\
\hline Total & $\mathbf{2 0 2 6}$ & $\mathbf{1 0 0}$ \\
\hline
\end{tabular}

Table 2: Tumor entities included into the subgroup analysis

\begin{tabular}{lc}
\hline Diagnosis & $\boldsymbol{n}$ \\
\hline Breast cancer & 476 \\
Glioma & 219 \\
Urothelial carcinoma & 211 \\
Neuroendocrine tumor & 193 \\
Rectal cancer & 157 \\
Meningioma & 110 \\
Hepatocellular carcinoma & 104 \\
Ovarian tumor & 86 \\
Prostatic cancer & 81 \\
Lung cancer & 51 \\
Cerebral lymphoma & 49 \\
Pituary adenoma & 41 \\
\hline Total & $\mathbf{1 7 7 8}$ \\
\hline
\end{tabular}

rectal cancer, prostatic cancer, and pituitary adenomas. In addition, in breast cancer and hepatocellular carcinoma, weak correlations between ADC and KI 67 were found. Therefore, ADC cannot be used as a proliferation biomarker in these entities.

Interestingly, the present data are almost concordant with those reported for associations between ADC and cell count in several tumors [14]. It has been shown that ADC correlated strongly with cell count in gliomas, ovarian cancer, and lung cancer [14]. Moderate correlations were identified between ADC and cell count in prostatic cancer, renal cell carcinoma, uterine cervical cancer, and head/neck squamous cell carcinomas [14]. Finally, weakto-moderate correlations were found in breast cancer 
and meningioma and weak correlation was identified in lymphomas [14]. This finding suggests that relationships between ADC and KI 67 as well with cell count are similar.

Beside the mentioned results, several problems were identified, which limited our meta-analysis. Firstly, there are only 12 tumor entities, which were involved into the work. Furthermore, only 7 entities, namely breast cancer, glioma, urothelial carcinoma, neuroendocrine tumors, rectal cancer, and meningioma contained relatively large patient samples ranging from 104 to 476 . In addition, as seen, significant heterogeneities among the studies for the same tumors were identified. For example, in the breast cancer, Kim et al. reported the correlation of 0.07 , but

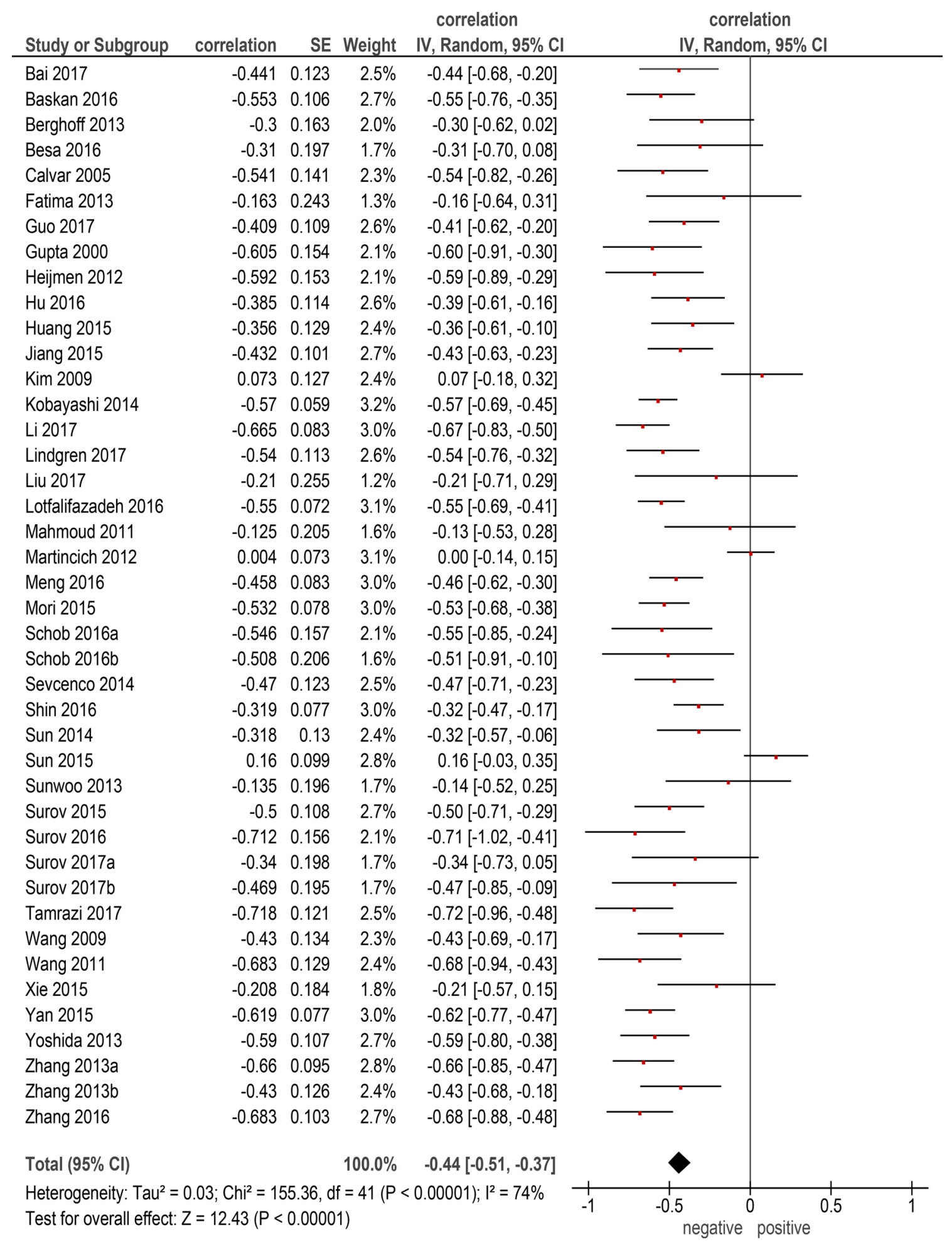

Figure 1: Forest plots of correlation coefficients between $\mathrm{ADC}_{\text {mean }}$ and $\mathrm{KI} 67$ in all involved studies $(n=42)$. 
correlation

correlation

Study or Subgroup correlation SE Weight IV, Random, $95 \% \mathrm{Cl}$

IV, Random, $95 \% \mathrm{Cl}$

1.2.1 Breast cancer

Kim 2009

$0.073 \quad 0.127 \quad 3.0 \%$

$0.07[-0.18,0.32]$

Martincich 2012

$0.004 \quad 0.073 \quad 3.9 \%$

$0.00[-0.14,0.15]$

Mori 2015

$\begin{array}{lll}-0.532 & 0.078 \quad 3.8 \%\end{array}$

$-0.53[-0.68,-0.38]$

Shin 2016

$-0.384 \quad 0.07 \quad 4.0 \%$

$-0.38[-0.52,-0.25]$

Subtotal $(95 \% \mathrm{Cl})$

$14.7 \% \quad-0.22[-0.50,0.06]$

Heterogeneity: Tau $^{2}=0.07 ; \mathrm{Chi}^{2}=35.25, \mathrm{df}=3(\mathrm{P}<0.00001) ; \mathrm{I}^{2}=91 \%$

Test for overall effect: $Z=1.54(P=0.12)$

1.2.2 Cerebral lymphoma

Schob 2016a

Zhang 2016

$\begin{array}{llll}-0.34 & 0.2 & 1.9 \% & -0.34[-0.73,0.05]\end{array}$

Subtotal $(95 \% \mathrm{Cl})$

$-0.683 \quad 0.103$

$3.4 \%$

$-0.68[-0.88,-0.48]$

$5.3 \% \quad-0.55[-0.88,-0.23]$

Heterogeneity: $\mathrm{Tau}^{2}=0.03 ; \mathrm{Chi}^{2}=2.32, \mathrm{df}=1(\mathrm{P}=0.13) ; \mathrm{I}^{2}=57 \%$

Test for overall effect: $Z=3.34(P=0.0008)$

\subsubsection{Glioma}

Bai 2017

Gupta 2000

$\begin{array}{lll}-0.441 & 0.123 & 3.0 \%\end{array}$

$-0.44[-0.68,-0.20]$

$\begin{array}{lll}-0.653 & 0.14 & 2.7 \%\end{array}$

$-0.65[-0.93,-0.38]$

Sunwoo 2013

$-0.135 \quad 0.196 \quad 2.0 \%$

$-0.14[-0.52,0.25]$

Yan 2015

$\begin{array}{ll}-0.619 & 0.077\end{array}$

$3.9 \%$

$-0.62[-0.77,-0.47]$

Subtotal $(95 \% \mathrm{Cl})$

$11.6 \%$

$-0.51[-0.69,-0.32]$

Heterogeneity: $\mathrm{Tau}^{2}=0.02 ; \mathrm{Chi}^{2}=6.61, \mathrm{df}=3(\mathrm{P}=0.09) ; \mathrm{I}^{2}=55 \%$

Test for overall effect: $Z=5.43(P<0.00001)$

1.2.4 Urothelial carcinoma

Kobayashi 2014

Sevcenco 2014

$\begin{array}{lll}-0.57 & 0.059\end{array}$

$\begin{array}{lll}-0.47 & 0.123\end{array}$

$4.2 \%$

$-0.57[-0.69,-0.45]$

$\begin{array}{ll}-0.59 & 0.107\end{array}$

$3.0 \%$

$-0.47[-0.71,-0.23]$

Yoshida 2013

Subtotal $(95 \% \mathrm{Cl})$

$3.3 \% \quad-0.59[-0.80,-0.38]$

$10.5 \% \quad-0.56[-0.65,-0.47]$

Heterogeneity: $\mathrm{Tau}^{2}=0.00 ; \mathrm{Chi}^{2}=0.64, \mathrm{df}=2(P=0.73) ; \mathrm{I}^{2}=0 \%$

Test for overall effect: $Z=11.73(P<0.00001)$

\subsubsection{Lung Cancer}

Liu 2017

$\begin{array}{lll}-0.21 & 0.255\end{array}$

Zhang 2013a

Subtotal $(95 \% \mathrm{Cl})$

$\begin{array}{ll}-0.66 & 0.095\end{array}$

$1.4 \%$

$-0.21[-0.71,0.29]$

$3.5 \% \quad-0.66[-0.85,-0.47]$

$4.9 \% \quad-0.50[-0.92,-0.07]$

Heterogeneity: $\mathrm{Tau}^{2}=0.06 ; \mathrm{Chi}^{2}=2.73, \mathrm{df}=1(\mathrm{P}=0.10) ; \mathrm{I}^{2}=63 \%$

Test for overall effect: $Z=2.30(P=0.02)$

\subsubsection{Meningioma}

Baskan 2016

Fatima 2013

Surov 2015

Subtotal $(95 \% \mathrm{Cl})$

Heterogeneity: $\mathrm{Tau}^{2}=0.02 ; \mathrm{Chi}^{2}=4.24, \mathrm{df}=2(P=0.12) ; \mathrm{I}^{2}=53 \%$

Test for overall effect: $Z=3.65(P=0.0003)$

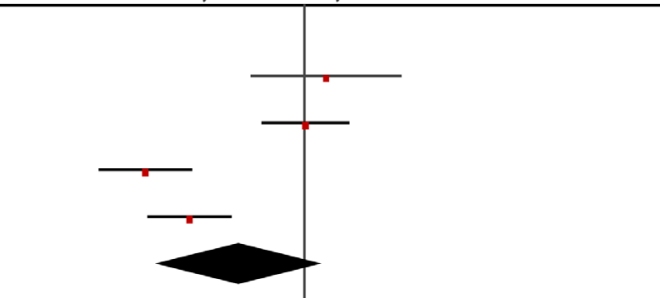




\subsubsection{Ovarian cancer}

$\begin{array}{lrrrr}\text { Li } 2017 & -0.665 & 0.083 & 3.8 \% & -0.67[-0.83,-0.50 \\ \text { Lindgren } 2017 & -0.54 & 0.113 & 3.2 \% & -0.54[-0.76,-0.32] \\ \text { Subtotal }(95 \% \mathrm{Cl}) & & & 7.0 \% & -0.62[-0.75,-0.49]\end{array}$

Heterogeneity: $\mathrm{Tau}^{2}=0.00 ; \mathrm{Chi}^{2}=0.79, \mathrm{df}=1(\mathrm{P}=0.37) ; \mathrm{I}^{2}=0 \%$

Test for overall effect: $Z=9.29(P<0.00001)$

1.2.8 Prostatic cancer

$\begin{array}{lllll}\text { Wang 2009 } & -0.43 & 0.134 & 2.8 \% & -0.43[-0.69,-0.17] \\ \text { Zhang 2013b } & -0.43 & 0.126 & 3.0 \% & -0.43[-0.68,-0.18] \\ \text { Subtotal }(95 \% \mathrm{Cl}) & & & 5.8 \% & -0.43[-0.61,-0.25]\end{array}$

Heterogeneity: $\mathrm{Tau}^{2}=0.00 ; \mathrm{Chi}^{2}=0.00, \mathrm{df}=1(P=1.00) ;\left.\right|^{2}=0 \%$

Test for overall effect: $Z=4.68(P<0.00001)$

1.2.9 Neuroendocrine tumor

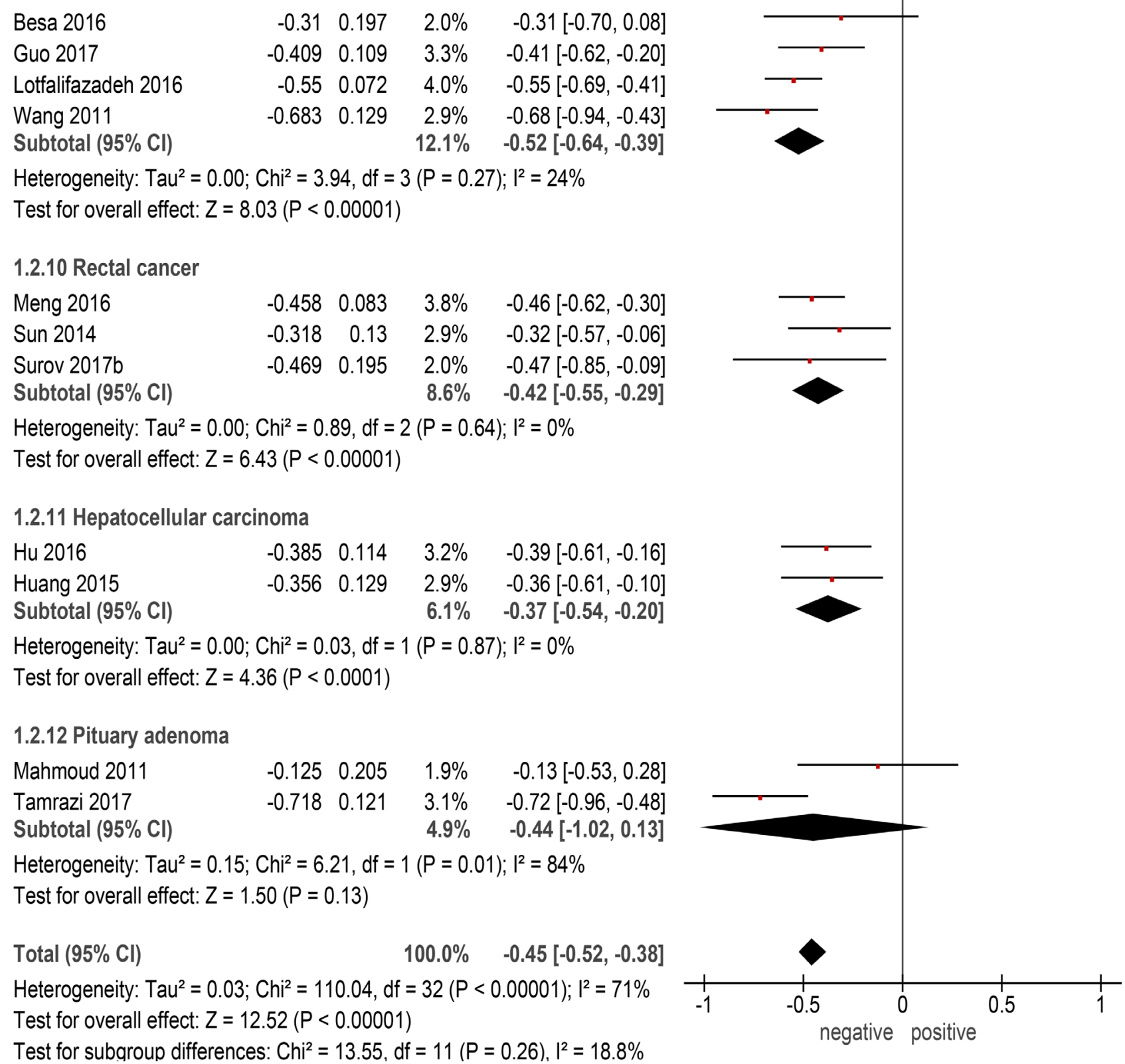

Figure 2: Forest plots of correlation coefficients between $\mathrm{ADC}_{\text {mean }}$ and $\mathrm{KI} 67$ in different primary tumors. 
in the study of Mori et al. it was -0.53 . This finding is difficult to ascertain. These variations of the published correlation coefficients were possibly due to different population of subjects, different ratio of tumor subtypes, or different method of analysis (ROI size, location, etc.). Clearly, the results of the present meta-analysis may be limited due this fact.

For other tumors, such as ovarian cancer, prostatic cancer, lung cancer, cerebral lymphoma, and pituitary adenoma, the number of patients was small ranging from 41 to 86 . This fact relativizes the validity of the estimated correlation coefficients.

Secondly, only one report was published for pancreatic carcinomas, thyroid cancer, head and neck squamous cell carcinoma, and uterine cervical cancer, respectively. Therefore, these tumors could not be included into the subgroups analysis.

Furthermore, we identified another great problem. To date, there are no reports about relationships between ADC and KI 67 in frequent and less frequent solid malignancies, such as colonic cancer, esophageal carcinoma, gastric cancer, gastrointestinal stromal tumors, renal cell carcinoma, different sarcomas, pleural and peritoneal mesotheliomas, thymic cancer, gall bladder cancer, and adrenal gland carcinoma. This is a purpose for further investigations.

In conclusion, several tumors showed different inverse correlations between ADC and KI 67. Strong correlation was found in ovarian cancer, and, therefore, $\mathrm{ADC}$ can be used as an imaging marker for proliferation potential in this entity.

In urothelial carcinoma, lung cancer, cerebral lymphoma, glioma, and neuroendocrine tumors moderate correlations were identified between ADC and KI 67. Therefore, use of ADC as a surrogate marker for proliferation potential in clinical practice is limited.

In meningiomas, rectal cancer, prostatic cancer, and pituitary adenomas, weak-to-moderate correlations and in breast cancer and hepatocellular carcinoma, weak correlations between ADC and KI 67 were found. This finding indicates that $\mathrm{ADC}$ cannot predict proliferation potential in these entities.

Finally, for other tumors, no evident data can be provided to date.

\section{MATERIALS AND METHODS}

\section{Data acquisition and proving}

The strategy of data acquisition is shown in Figure 3. MEDLINE library was screened for associations between ADC and KI 67 in different tumors up to April 2017. The following search words were used: "DWI or diffusion weighted imaging or diffusion-weighted imaging or ADC or apparent diffusion coefficient AND KI 67 OR KI67 OR ki67 OR ki-67 OR mitotic index OR proliferation index

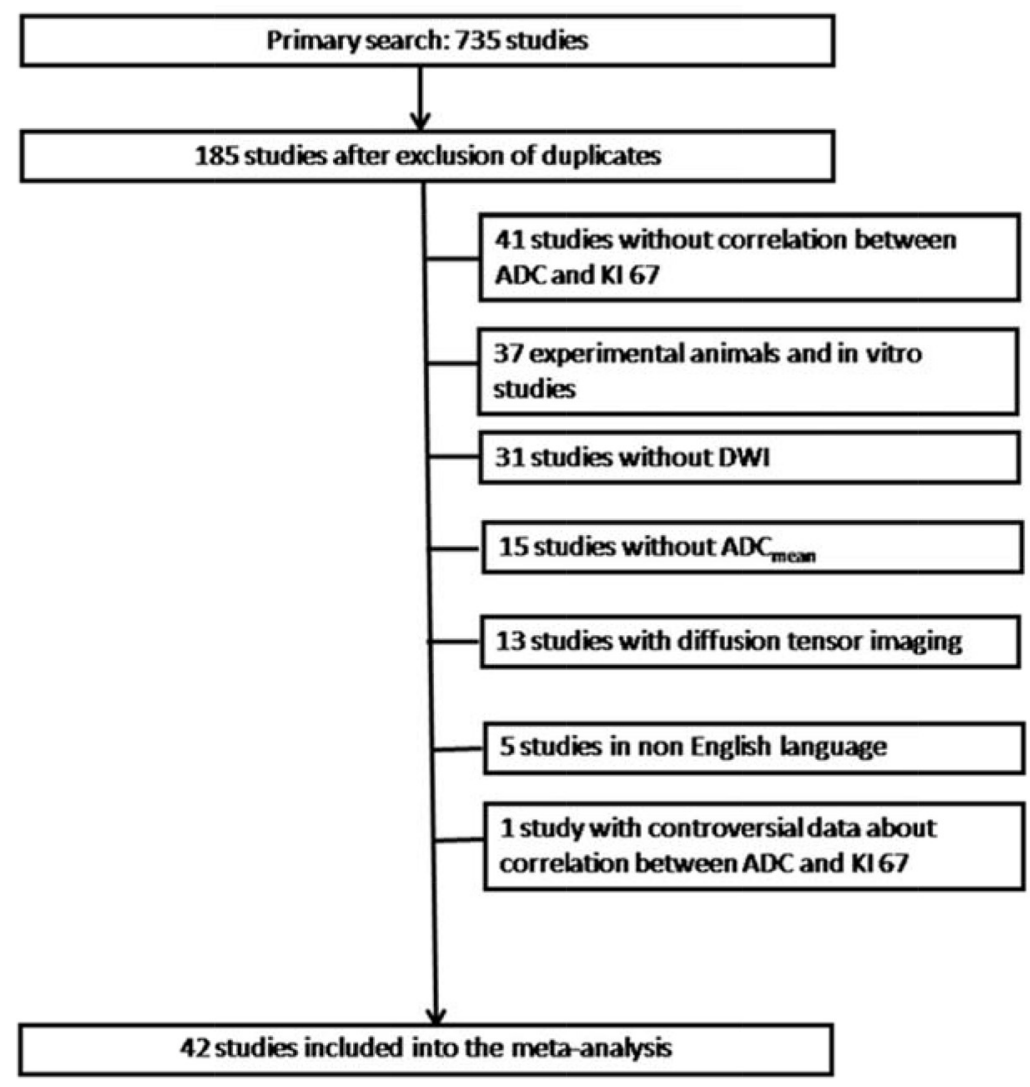

Figure 3: Flowchart of the study selection. 
Table 3: Methodological quality of the involved 42 studies according to the QUADAS criteria

\begin{tabular}{lccc}
\hline QUADAS criteria & yes (\%) & no (\%) & unclear (\%) \\
\hline Patient spectrum & $40(95.24)$ & & $2(4.76)$ \\
Selection criteria & $29(69.05)$ & $12(28.57)$ & $1(2.38)$ \\
Reference standard & $42(100)$ & & \\
Disease progression bias & $42(100)$ & & \\
Partial vertification bias & $42(100)$ & & \\
Differential vertification bias & $42(100)$ & & \\
Incorporation bias & $42(100)$ & & \\
Text details & $42(100)$ & $10(23.81)$ & $14(33.33)$ \\
Reference standard details & $42(100)$ & $12(23.81)$ & $12.57)$ \\
Text review details & $18(42.86)$ & & $1(2.38)$ \\
Diagnostic review bias & $20(47.62)$ & & \\
Clinical review bias & $40(95.24)$ & & \\
Uninterpretable results & $42(100)$ & & \\
Withdrawls explained & $40(95.24)$ & & \\
\hline
\end{tabular}

OR MIB 1 OR MIB-1 OR mitosis index". Secondary references were also recruited. The Preferred Reporting Items for Systematic Reviews and Meta-Analyses statement (PRISMA) was used for the research [66].

Overall, 735 records were identified. After exclusion of duplicates $(n=550)$, a total of 185 publications were included into the further analysis. For this work, only data regarding $\mathrm{ADC}_{\text {mean }}$ derived from diffusion weighted imaging (DWI) were collected. Overall, 143 publications were excluded. There were 31 studies without DWI, 5 non English publications, 41 publications, which did not contain correlation coefficients between ADC and KI 67, and 37 experimental animals and in vitro studies. Furthermore, data retrieved from diffusion tensor imaging and studies with other than $\mathrm{ADC}_{\text {mean }}$ parameters were also excluded $(n=28)$. Finally, we excluded one study with wrong data regarding correlation coefficient between ADC and KI 67. Therefore, the present analysis comprises 42 studies with 2026 patients [17-59]. The following data were extracted from the literature: authors, year of publication, number of patients, tumor type, and correlation coefficients.

\section{Meta-analysis}

The methodological quality of the 42 studies was independently checked by two observers (A.S. and H.J.M.) using the Quality Assessment of Diagnostic Studies (QUADAS) instrument according to previous descriptions $[67,68]$. Table 3 shows the results of QUADAS proving.

Associations between $\mathrm{ADC}_{\text {mean }}$ and $\mathrm{KI} 67$ were analyzed by Spearman's correlation coefficient. The reported Pearson correlation coefficients in some studies were converted into Spearman correlation coefficients according to the previous description [69].
Furthermore, the meta-analysis was undertaken by using RevMan 5.3 (Computer program, version 5.3. Copenhagen: The Nordic Cochrane Centre, The Cochrane Collaboration, 2014). Heterogeneity was calculated by means of the inconsistency index $\mathrm{I}^{2}[70,71]$. In a subgroup analysis, studies were stratified by tumor type. In addition, DerSimonian and Laird random-effects models with inverse-variance weights were used without any further correction [72].

\section{REFERENCES}

1. Fornasa F. Diffusion-weighted Magnetic Resonance Imaging: What Makes Water Run Fast or Slow? J Clin Imaging Sci. 2011; 1:27.

2. Surov A, Caysa H, Wienke A, Spielmann RP, Fiedler E. Correlation between different ADC fractions, cell count, $\mathrm{Ki}-67$, total nucleic areas and average nucleic areas in meningothelial meningiomas. Anticancer Res. 2015; 35:6841-6.

3. Sinkus R, Van Beers BE, Vilgrain V, DeSouza N, Waterton JC. Apparent diffusion coefficient from magnetic resonance imaging as a biomarker in oncology drug development. Eur J Cancer. 2012; 48:425-31.

4. Hamstra DA, Rehemtulla A, Ross BD. Diffusion magnetic resonance imaging: a biomarker for treatment response in oncology. J Clin Oncol. 2007; 25:4104-9.

5. Harry VN, Semple SI, Parkin DE, Gilbert FJ. Use of new imaging techniques to predict tumour response to therapy. Lancet Oncol. 2010; 11:92-102.

6. Ajithkumar T, Price S, Horan G, Burke A, Jefferies S. Prevention of radiotherapy-induced neurocognitive dysfunction in survivors of paediatric brain tumours: the potential role of modern imaging and radiotherapy techniques. Lancet Oncol. 2017; 18:e91-e100. 
7. Padhani AR, Liu G, Koh DM, Chenevert TL, Thoeny HC, Takahara T, Dzik-Jurasz A, Ross BD, Van Cauteren M, Collins D, Hammoud DA, Rustin GJ, Taouli B, Choyke PL. Diffusion-weighted magnetic resonance imaging as a cancer biomarker: consensus and recommendations. Neoplasia. 2009; 11:102-25.

8. Hamstra DA, Galbán CJ, Meyer CR, Johnson TD, Sundgren PC, Tsien C, Lawrence TS, Junck L, Ross DJ, Rehemtulla A, Ross BD, Chenevert TL. Functional diffusion map as an early imaging biomarker for high-grade glioma: correlation with conventional radiologic response and overall survival. J Clin Oncol. 2008; 26:3387-94.

9. Wang J, Takashima S, Takayama F, Kawakami S, Saito A, Matsushita T, Momose M, Ishiyama T. Head and neck lesions: characterization with diffusion-weigted echoplanar MR imaging. Radiology. 2001; 220:621-30.

10. Kyriazi S, Collins DJ, Messiou C, Pennert K, Davidson RL, Giles SL, Kaye SB, Desouza NM. Metastatic ovarian and primary peritoneal cancer: assessing chemotherapy response with diffusion-weighted MR imaging — value of histogram analysis of apparent diffusion coefficients. Radiology. 2011; 261:182-92.

11. Bollineni VR, Kramer G, Liu Y, Melidis C, deSouza NM. A literature review of the association between diffusionweighted MRI derived apparent diffusion coefficient and tumour aggressiveness in pelvic cancer. Cancer Treat Rev. 2015; 41:496-502.

12. Sun YS, Cui Y, Tang L, Qi LP, Wang N, Zhang XY, Cao K, Zhang XP. Early evaluation of cancer response by a new functional biomarker: apparent diffusion coefficient. AJR Am J Roentgenol. 2011; 197:W23-W9.

13. Papaevangelou E, Almeida GS, Jamin Y, Robinson SP, deSouza NM. Diffusion-weighted MRI for imaging cell death after cytotoxic or apoptosis-inducing therapy. Br J Cancer. 2015; 112:1471-9.

14. Surov A, Meyer HJ, Wienke A. Correlation between apparent diffusion coefficient (ADC) and cellularity is different in several tumors: a meta-analysis. Oncotarget. 2017; 8:594929. https://doi.org/10.18632/oncotarget.17752.

15. Choi SY, Chang YW, Park HJ, Kim HJ, Hong SS, Seo DY. Correlation of the apparent diffusion coefficiency values on diffusion-weighted imaging with prognostic factors for breast cancer. Br J Radiol. 2012; 85:e474-9.

16. Surov A, Ginat DT, Sanverdi E, Lim CCT, Hakyemez B, Yogi A, Cabada T, Wienke A. Use of diffusion weighted imaging in differentiating between malignant and benign meningiomas. A multicenter analysis. World Neurosurg. 2016; 88:598-602.

17. Schob S, Meyer HJ, Gawlitza M, Frydrychowitz C, Müller W, Preuss M, Bure L, Quäschling U, Hoffmann KT, Surov A. Diffusion-weighted imaging reflects proliferative activity in primary CNS lymphoma. PloS One. 2016; 11:e0161386.

18. Kim SH, Cha ES, Kim HS, Kang BJ, Choi JJ, Jung JH, Park YG, Suh YJ. Diffusion-weighted imaging of breast cancer: correlation of the apparent diffusion coefficient value with prognostic factors. J Magn Reson Imaging. 2009; 30:615-20.

19. Surov A, Gottschling S, Mawrin C, Prell J, Spielmann RP, Wienke A, Fiedler E. Diffusion-Weighted Imaging in Meningioma: Prediction of Tumor Grade and Association with Histopathological Parameters. Transl Oncol. 2015; 8:517-23.

20. Sun Y, Tong T, Cai S, Bi R, Xin C, Gu Y. Apparent Diffusion Coefficient (ADC) value: a potential imaging biomarker that reflects the biological features of rectal cancer. PLoS One. 2014; 9:e109371.

21. Yan R, Haopeng P, Xiaoyuan F, Jinsong W, Jiawen Z, Chengjun Y, Tianming Q, Ji X, Mao S, Yueyue D, Yong Z, Jianfeng L, Zhenwei Y. Non-Gaussian diffusion MR imaging of glioma: comparisons of multiple diffusion parameters and correlation with histologic grade and MIB-1 (Ki-67 labeling) index. Neuroradiology. 2016; 58:121-32.

22. Surov A, Stumpp P, Meyer HJ, Gawlitza M, Höhn AK, Boehm A, Sabri O, Kahn T, Purz S. Simultaneous (18) F-FDG-PET/MRI: Associations between diffusion, glucose metabolism and histopathological parameters in patients with head and neck squamous cell carcinoma. Oral Oncol. 2016; 58:14-20.

23. Gupta RK, Cloughesy TF, Sinha U, Garakian J, Lazareff J, Rubino G, Rubino L, Becker DP, Vinters HV, Alger JR. Relationships between choline magnetic resonance spectroscopy, apparent diffusion coefficient and quantitative histopathology in human glioma. J Neurooncol. 2000; 50:215-26.

24. Sevcenco S, Haitel A, Ponhold L, Susani M, Fajkovic H, Shariat SF, Hiess M, Spick C, Szarvas T, Baltzer PA. Quantitative apparent diffusion coefficient measurements obtained by 3-Tesla MRI are correlated with biomarkers of bladder cancer proliferative activity. PLoS One. 2014; 9:e106866.

25. Wang Y, Chen ZE, Yaghmai V, Nikolaidis P, McCarthy RJ, Merrick L, Miller FH. Diffusion-weighted MR imaging in pancreatic endocrine tumors correlated with histopathologic characteristics. J Magn Reson Imaging. 2011; 33:1071-9.

26. Liu LP, Zhang XX, Cui LB, Li J, Yang JL, Yang HN, Zhang Y, Zhou Y, Tang X, Qi S, Fang Y, Zhang J, Yin H.Preliminary comparison of diffusion-weighted MRI, $\mathrm{PET} / \mathrm{CT}$ in predicting histological type and malignancy of lung cancer. Clin Respir J. 2017; 11:151-8.

27. Fatima Z, Motosugi U, Waqar AB, Hori M, Ishigame K, Oishi N, Onodera T, Yagi K, Katoh R, Araki T. Associations among q-space MRI, diffusion-weighted MRI and histopathological parameters in meningiomas. Eur Radiol. 2013; 23:2258-63.

28. Martincich L, Deantoni V, Bertotto I, Redana S, Kubatzki F, Sarotto I, Rossi V, Liotti M, Ponzone R, Aglietta M, Regge D, Montemurro F. Correlations between diffusion-weighted imaging and breast cancer biomarkers. Eur Radiol. 2012; 22:1519-28. 
29. Kobayashi S, Koga F, Kajino K, Yoshita S, Ishii C, Tanaka H, Saito K, Masuda H, Fujii Y, Yamada T, Kihara K. Apparent diffusion coefficient value reflects invasive and proliferative potential of bladder cancer. J Magn Reson Imaging. 2014; 39:172-8.

30. Shin HJ, Kim SH, Lee HJ, Gong G, Baek S, Chae EY, Choi WJ, Cha JH, Kim HH. Tumor apparent diffusion coefficient as an imaging biomarker to predict tumor aggressiveness in patients with estrogen-receptor-positive breast cancer. NMR Biomed. 2016; 29:1070-8.

31. Bai Y, Lin Y, Zhang W, Kong L, Wang L, Zuo P, Vallines I, Schmitt B, Tian J, Song X, Zhou J, Wang M. Noninvasive amide proton transfer magnetic resonance imaging in evaluating the grading and cellularity of gliomas. Oncotarget. 2017; 8:5834-42. https://doi.org/10.18632/oncotarget.13970.

32. Baskan O, Silav G, Bolukbasi FH, Canoz O, Geyik I, Elmaci I.Relation of apparent diffusion coefficient with $\mathrm{Ki}-67$ proliferation index in meningiomas. Br J Radiol. 2016; 89:20140842.

33. Berghoff AS, Spanberger T, Ilhan-Mutlu A, Magerle M, Hutterer M, Woehrer A, Hackl M, Widhalm G, Dieckmann K, Marosi C, Birner P, Prayer D, Preusser M. Preoperative diffusion-weighted imaging of single brain metastases correlates with patient survival times. PLoS One. 2013; 8:e55464.

34. Besa C, Ward S, Cui Y, Jajamovich G, Kim M, Taouli B. Neuroendocrine liver metastases: Value of apparent diffusion coefficient and enhancement ratios for characterization of histopathologic grade. J Magn Reson Imaging. 2016; 44:1432-41.

35. Calvar JA, Meli FJ, Romero C, Calcagno ML, Yánez P, Martinez AR, Lambre H, Taratuto AL, Sevlever G. Characterization of brain tumors by MRS, DWI, Ki-67 labeling index. J Neurooncol. 2005; 72:273-80.

36. Guo C, Chen X, Xiao W, Wang Q, Sun K, Wang Z. Pancreatic neuroendocrine neoplasms at magnetic resonance imaging: comparison between grade 3 and grade 1/2 tumors. Onco Targets Ther. 2017; 10:1465-74.

37. Heijmen L, TerVoert EE, Nagtegaal ID, Span $P$, Bussink J, Punt CJ, de Wilt JH, Sweep FC, Heerschap A, van Laarhoven HW. Diffusion-weighted MR imaging in liver metastases of colorectal cancer: reproducibility and biological validation. Eur Radiol. 2013; 23:748-56.

38. Hu XX, Yang ZX, Liang HY, Ding Y, Grimm R, Fu CX, Liu H, Yan X, Ji Y, Zeng MS, Rao SX. Whole-tumor MRI histogram analyses of hepatocellular carcinoma: Correlations with Ki-67 labeling index. J Magn Reson Imaging. 2017; 46:383-392.

39. Huang Z, Xu X, Meng X, Hou Z, Liu F, Hua Q, Liu Q, Xiu J. Correlations between ADC values and molecular markers of Ki-67 and HIF-1 $\alpha$ in hepatocellular carcinoma. Eur J Radiol. 2015; 84:2464-9.

40. Jiang R, Jiang J, Zhao L, Zhang J, Zhang S, Yao Y, Yang S, Shi J, Shen N, Su C, Zhang J, Zhu W. Diffusion kurtosis imaging can efficiently assess the glioma grade and cellular proliferation. Oncotarget. 2015; 6:42380-93. https://doi. org/10.18632/oncotarget.5675.

41. Li HM, Zhao SH, Qiang JW, Zhang GF, Feng F, Ma FH, Li YA, Gu WY. Diffusion kurtosis imaging for differentiating borderline from malignant epithelial ovarian tumors: A correlation with Ki-67 expression. J Magn Reson Imaging. 2017 Mar 10. https://doi.org/10.1002/jmri.25696.

42. Lindgren A, Anttila M, Rautiainen S, Arponen O, Kivelä A, Mäkinen P, Härmä K, Hämäläinen K, Kosma VM, YläHerttuala S, Vanninen R, Sallinen H. Primary and metastatic ovarian cancer: Characterization by 3.0T diffusion-weighted MRI. Eur Radiol. 2017 Mar 13. https://doi.org/10.1007/ s00330-017-4786-z.

43. Lotfalizadeh E, Ronot M, Wagner M, Cros J, Couvelard A, Vullierme MP, Allaham W, Hentic O, Ruzniewski P, Vilgrain V. Prediction of pancreatic neuroendocrine tumour grade with MR imaging features: added value of diffusionweighted imaging. Eur Radiol. 2017; 27:1748-59.

44. Mahmoud OM, Tominaga A, Amatya VJ, Ohtaki M, Sugiyama K, Sakoguchi T, Kinoshita Y, Takeshima Y, Abe N, Akiyama Y, El-Ghoriany AI, AbdAlla AK, El-Sharkawy MA, et al. Role of PROPELLER diffusion-weighted imaging and apparent diffusion coefficient in the evaluation of pituitary adenomas. Eur J Radiol. 2011; 80:412-7.

45. Meng X, Li H, Kong L, Zhao X, Huang Z, Zhao H, Zhu W, Li X, Yu J, Xing L.MRI In rectal cancer: Correlations between MRI features and molecular markers Ki-67, HIF$1 \alpha$, and VEGF. J Magn Reson Imaging. 2016; 44:594-600.

46. Mori N, Ota H, Mugikura S, Takasawa C, Ishida T, Watanabe G, Tada H, Watanabe M, Takase K, Takahashi S. Luminal-type breast cancer: correlation of apparent diffusion coefficients with the Ki-67 labeling index. Radiology. 2015; 274:66-73.

47. Schob S, Voigt P, Bure L, Meyer HJ, Wickenhauser C, Behrmann C, Höhn A, Kachel P, Dralle H, Hoffmann KT, Surov A. Diffusion-Weighted Imaging Using a Readout-Segmented, Multishot EPI Sequence at $3 \mathrm{~T}$ Distinguishes between Morphologically Differentiated and Undifferentiated Subtypes of Thyroid Carcinoma-A Preliminary Study. Transl Oncol. 2016; 9:403-10.

48. Sun K, Chen X, Chai W, Fei X, Fu C, Yan X, Zhan Y, Chen K, Shen K, Yan F. Breast Cancer: Diffusion Kurtosis MR Imaging-Diagnostic Accuracy and Correlation with Clinical-Pathologic Factors. Radiology. 2015; 277:46-55.

49. Sunwoo L, Choi SH, Park CK, Kim JW, Yi KS, Lee WJ, Yoon TJ, Song SW, Kim JE, Kim JY, Kim TM, Lee SH, Kim JH, et al. Correlation of apparent diffusion coefficient values measured by diffusion MRI, MGMT promoter methylation semiquantitatively analyzed with MS-MLPA in patients with glioblastoma multiforme. J Magn Reson Imaging. 2013; 37:351-8.

50. Surov A, Meyer HJ, Schob S, Höhn AK, Bremicker K, Exner M, Stumpp P, Purz S. Parameters of simultaneous 18 F-FDG-PET/MRI predict tumor stage and several 
histopathological features in uterine cervical cancer. Oncotarget. 2017; 8:28285-96. https://doi.org/10.18632/ oncotarget.16043.

51. Surov A, Meyer HJ, Höhn AK, Behrmann C, Wienke A, Spielmann RP, Garnov N. Correlations between intravoxel incoherent motion (IVIM) parameters and histological findings in rectal cancer: preliminary results. Oncotarget. 2017; 8:21974-83. https://doi.org/10.18632/ oncotarget. 15753.

52. Tamrazi B, Pekmezci M, Aboian M, Tihan T, Glastonbury CM. Apparent diffusion coefficient and pituitary macroadenomas: pre-operative assessment of tumor atypia. Pituitary. 2017; 20:195-200.

53. Wang XZ, Wang B, Gao ZQ, Liu JG, Liu ZQ, Niu QL, Sun ZK, Yuan YX. Diffusion-weighted imaging of prostate cancer: correlation between apparent diffusion coefficient values and tumor proliferation. J Magn Reson Imaging. 2009; 29:1360-6.

54. Xie P, Liu K, Peng W, Zhou Z.The Correlation Between Diffusion-Weighted Imaging at 3.0-T Magnetic Resonance Imaging and Histopathology for Pancreatic Ductal Adenocarcinoma. J Comput Assist Tomogr. 2015; 39:697-701.

55. Yan R, Haopeng P, Xiaoyuan F, Jinsong W, Jiawen Z, Chengjun Y, Tianming Q, Ji X, Mao S, Yueyue D, Yong Z, Jianfeng L, Zhenwei Y. Non-Gaussian diffusion MR imaging of glioma: comparisons of multiple diffusion parameters and correlation with histologic grade and MIB1 (Ki-67 labeling) index. Neuroradiology. 2016; 58:121-32.

56. Yoshida S, Kobayashi S, Koga F, Ishioka J, Ishii C, Tanaka H, Nakanishi Y, Matsuoka Y, Numao N, Saito K, Masuda H, Fujii Y, Kihara K. Apparent diffusion coefficient as a prognostic biomarker of upper urinary tract cancer: a preliminary report. Eur Radiol. 2013; 23:2206-14.

57. Zhang J, Cui LB, Tang X, Ren XL, Shi JR, Yang HN, Zhang Y, Li ZK, Wu CG, Jian W, Zhao F, Ti XY, Yin H. DW MRI at 3.0 T versus FDG PET/CT for detection of malignant pulmonary tumors. Int J Cancer. 2014; 134:606-11.

58. Zhang J, Jing $\mathrm{H}$, Han $\mathrm{X}$, Huang Z, Cao Z, Liu Q. Diffusion-weighted imaging of prostate cancer on 3T MR: Relationship between apparent diffusion coefficient values and Ki-67 expression. Acad Radiol. 2013; 20:1535-41.

59. Zhang Y, Zhang Q, Wang XX, Deng XF, Zhu YZ. Value of pretherapeutic DWI in evaluating prognosis and therapeutic effect in immunocompetent patients with primary central nervous system lymphoma given high-dose methotrexatebased chemotherapy: ADC-based assessment. Clin Radiol. 2016; 71:1018-29.

60. He X, Chen Z, Fu T, Jin X, Yu T, Liang Y, Jin X, Yu T, Liang Y, Zhao X, Huang L. Ki-67 is a valuable prognostic predictor of lymphoma but its utility varies in lymphoma subtypes: evidence from a systematic meta-analysis. BMC Cancer. 2014; 14:1-13.
61. Schlüter C, Duchrow M, Wohlenberg C, Becker MH, Key G, Flad HD, Gerdes J. The cell proliferation-associated antigen of antibody Ki-67: a very large, ubiquitous nuclear protein with numerous repeated elements, representing a new kind of cell cycle-maintaining proteins. J Cell Biol. 1993; 123:513-22.

62. Jorgensen P, Edgington NP, Schneider BL, Rupeš I, Tyers $\mathrm{M}$, Futcher B. The size of the nucleus increases as yeast cells grow. Mol Biol Cell. 2007; 18:3523-32.

63. Driessen JP, Caldas-Magalhaes J, Janssen LM, Pameijer FA, Kooij N, Terhaard CH, Grolman W, Philippens ME. Diffusion-weighted MR Imaging in Laryngeal and Hypopharyngeal Carcinoma: Association between Apparent Diffusion Coefficient and Histologic Findings. Radiology. 2014; 272:456-63.

64. Mitchison JM. Growth during the cell cycle. Int Rev Cytol. 2003; 226:165-258.

65. Valentine MT, Perlman ZE, Mitchison TJ, Weitz DA. Mechanical properties of Xenopus egg cytoplasmic extracts. Biophys J. 2005; 88:680-9.

66. Moher D, Liberati A, Tetzlaff J, Altman DG. Preferred reporting items for systematic reviews and meta-analyses: the PRISMA statement. PLoS Med. 2009; 6:e1000097.

67. Whiting P, Rutjes AW, Reitsma JB, Bossuyt PM, Kleijnen J. The development of QUADAS: a tool for the quality assessment of studies of diagnostic accuracy included in systematic reviews. BMC Med Res Methodol. 2003; 3:25.

68. Whiting PF, Weswood ME, Rutjes AW, Reitsma JB, Bossuyt PN, Kleijnen J. Evaluation of QUADAS, a tool for the quality assessment of diagnostic accuracy studies. BMC Med Res Methodol. 2006; 6:9.

69. Chalkidou A, Landau DB, Odell EW, Cornelius VR, O`Doherty MJ, Marsden PK. Correlation between Ki-67 immunohistochemistry and 18F-fluorothymidine uptake in patients with cancer: A systematic review and metaanalysis. Eur J Cancer. 2012; 48:3499-513.

70. Leeflang MM, Deeks JJ, Gatsonis C, Bossuyt PM. Systematic reviews of diagnostic test accuracy. Ann Intern Med. 2008; 149:889-97.

71. Zamora J, Abraira V, Muriel A, Khan K, Coomarasamy A. Meta-DiSc: A software for meta-analysis of test accuracy data. BMC Medical Research Methodology. 2006; 6:31.

72. DerSimonian R, Laird N. Meta-analysis in clinical trials. Controlled Clinical Trials. 1986; 7:177-88. 